\title{
Determination of antimicrobial and anti-quorum sensing activities of water and ethanol extracts of propolis
}

\author{
Ali SORUCU ${ }^{1, a \unrhd, ~ O ̈ z g u ̈ r ~ C E Y L A N ~}{ }^{2, b}$ \\ ${ }^{1}$ Muğla Sitkı Koçman University, Faculty of Milas Veterinary Medicine, Department of Pharmacology and Toxicology, Muğla, \\ Turkey; ${ }^{2}$ Mugla Sitki Kocman University, Ali Kocman Vocational School, Food Quality Control and Analysis Program. Mugla, \\ Turkey. \\ ${ }^{\mathrm{a} O R C I D}$ 0000-0002-0496-9498; ${ }^{\mathrm{b}}$ ORCID 0000-0002-1865-1093
}

${ }^{\bowtie}$ Corresponding author: alisorucu@mu.edu.tr

Received date: 11.09.2020 - Accepted date: 05.01.2021

\begin{abstract}
Quorum Sensing is a special system between bacteria to communicate with the signal molecules. Propolis is a resin collected from plants by honey bees. The present study examined anti-quorum sensing and antimicrobial activities of water and ethanol extracts of propolis. The antimicrobial activities of the propolis extracts were studied against Escherichia coli ATCC 25922 Gram (-), Listeria monocytogenes ATCC 7644, Streptococcus mutans CNCTC 8/77, Staphylococcus aureus ATCC 25923 Gram (+), Candida albicans ATCC 10239 (yeast) by the well diffusion method. Anti-quorum sensing activity, violacein inhibition activity, and antiswarming activity were studied using Chromobacterium violaceum CV026 and C. violaceum ATCC 112472, and Pseudomonas aeruginosa (PA01) respectively. Both propolis extracts were detected antibacterial activity against Gram $(+)$ bacteria and Candida albicans. However, antibacterial activity against Gram (-) bacteria were not observed. While the antimicrobial activity of water extract propolis was determined more effectively than ethanol extract, anti-quorum sensing and anti-swarming activities less effective. It was also detected that both extracts display violacein inhibition. It was revealed that the antimicrobial, anti-quorum sensing, anti-swarming activity depended on the dose of propolis extracts. Thirty-six phenolic compounds were analysed of propolis extract by HPLC-DAD. The amount and presence of phenolic compounds in the ethanol extract were more than the water extract apart from benzoic acid, cinnamic acid, syringic acid, $( \pm$ ) epigallocatechin, vitexin, rutin, and trans-chalcone. Consequently, the study put forward that the phenolic compounds of propolis have antibacterial, anti- quorum sensing, violacein inhibition, and anti-swarming activities changing depend on directly the extraction solvent and phenolic compounds.
\end{abstract}

Keywords: Antimicrobial activity, anti-quorum sensing activity, anti-swarming activity, propolis, violacein inhibition activity.

\section{Propolisin sulu ve etanol ekstresinin antimikrobiyal ve anti-çoğunluk algılama aktivitesinin belirlenmesi}

Özet: Çoğunluğu algılama sistemi bakterilerin sinyal molekülleri ile kendi aralarında iletişim kurmasını sağlayan özel bir sistemdir. Propolis bal arılarının bitkilerden topladığı reçinedir. Bu çalışmada etanol ve su ekstrakt propolisin antimikrobiyal ve antiçoğunluk algılama aktivitesi incelendi. Propolis ekstraktlarının antimikrobiyal aktivitesi Escherichia coli ATCC 25922, Listeria monocytogenes ATCC 7644, Streptococcus mutans CNCTC 8/77, Staphylococcus aureus ATCC 25923 ve Candida albicans ATCC 102392'e karşı disk difüzyon yöntemi ile çalışıldı. Anti-çoğunluk algılama, violacein inhibisyon ve kaynaşma önleyici aktiviteleri sırasıyla Chromobacterium violaceum CV026, C. violaceum ATCC 112472 ve Pseudomonas aeruginosa PA01 ile çalış1ldı. Propolis ekstraktlarının Gram (+) bakteriler ve Candida albicans üzerine antimikrobiyal etkisi olmasına rağmen Gram (-) bakterilerde herhangi bir etki tespit edilememiştir. Sulu ektrakt propolisin antibakteriyel aktivitesi etanol ekstrakt propolise göre daha yüksek iken antiçoğunluk algılama ve kaynaşma önleyici aktivitesi daha az olduğu tespit edildi. Violacein inhibisyon aktivitesi ise her iki propolis ekstraktında da tespit edildi. Propolis ekstraktlarının antibakteriyel, anti-çoğunluk algılama ve kaynaşma önleyici aktiviteleri doza bağımlı olarak değiştiği görüldü. Propolis ekstraktlarında otuz altı fenolik bileşik HPLC-DAD ile analiz edildi. Benzoik asit, sinnamik asit, şiringik asit, epigallokateşin, viteksin rutin ve kalkon dışındaki tüm fenolik bileşikler hem miktarı hem de yaygınlığı etanol ekstrakt propoliste daha yüksek olduğu belirlendi. Sonuç olarak bu çalışma propolisin ekstraksiyon solventine ve içeriğindeki fenolik bileşiklere bağlı olarak antimikrobiyal, anti-çoğunluk algılama, violacein inhibisyon ve kaynaşma önleyici aktivitelerinin olduğunu ortaya koydu.

Anahtar sözcükler: Antimikrobiyal aktivite, anti-çoğunluk algılama aktivitesi, kaynaşma önleyici aktivitesi, propolis, violacein inhibisyon aktivitesi. 


\section{Introduction}

Honeybees collect the propolis from resin and bud exudates of plants $(3,17,30)$. Propolis is used as a building and protection material by honey bees, which fills holes and cracks, repairing of honeycombs in the hive, narrowing the beehive entrance against harmful creatures, and cold (30). The chemical composition of propolis is affected primarily by vegetation, that is the source of propolis, and secondly, by seasons as well as by altitudes both of which affect the vegetation (33). The biological activities of propolis are dependent on its chemical constituents, mainly phenolic compounds (3). Propolis has a vigorous antimicrobial activity known as a natural antibiotic. Many researches revealed the antibacterial effect of propolis on many bacteria by using different solvents and techniques (7). Antibacterial activity of propolis has found to be high against Gram-positive bacteria and weak against Gram-negative bacteria (7, 25, 30). Propolis has antibacterial activity on many resistant bacteria such as methicillin-resistant Staphylococcus aureus and vancomycin-resistant enterococci, which are dangerous for human and animal health $(2,21,31)$. Studies show that the antibacterial activity of propolis is due to inhibition of protein synthesis and disruption of cytoplasmic membrane integrity and permeability of bacteria (7). The bacteria have developed resistance to many antibacterial agents thanks to genetic mutation, quorum sensing (QS) activities, and changing of the antibacterial target (10).

The QS is a cell-to-cell communication mechanism dependent on cell density, which allows bacterial populations to regulate the expression of genes and release chemical signal molecules called auto-inducers (10). Bacteria producing the auto-inducer may change their phenotype so that their metabolism and other activities can be successful in the new environment (10). The autoinducers are responsible for biological behaviors which are biofilm formation, virulence symbiosis, sporulation, competence, motility, conjugation, and antibiotic production in the different bacteria using $\mathrm{N}$-acyl homoserine lactones (AHL) and oligopeptides (1, 10, 26, 32). Previous studies have determined the anti-QS activity of many natural products. Phenolic compounds, terpenoids, and oils found in natural products which are responsible for the anti-QS activity $(1,32)$. Some studies have also determined the anti-QS activity of propolis, which containing various phenolic components $(5,16)$. Chemical composition of propolis may change primarily depending on seasons, altitudes, and climate zone, which are pre-collecting factors that directly concerning vegetation around apiaries (33). Secondly, the chemical composition of propolis is affected significantly by the extraction method and its solvent, which are postcollecting factors $(15,34)$.
The present study was aimed to determine and compare the anti-QS and antimicrobial activities of the water and ethanol extracts of propolis, which collected from Bursa in Turkey. Moreover, it was studied antimicrobial and anti-QS activities related to the content of phenolic compounds in propolis.

\section{Materials and Methods}

Chemical and Reagents: Biomonitor strains used in the anti-QS studies were growth on Luria-Bertani broth. Other bacteria were fed on Brain Heart Infusion Broth (BHIB), Sabouraud Dextrose Broth (SDB), Nutrient Broth, Luria Bertani Broth, and Mueller Hinton Broth over agar (Merck). 24-well cell culture plates (Greiner Bio-One, Kremsmünster, Austria, sterile, with lid), Nhexanoyl-DL-homoserine lactone (C6-HSL, $\geq 97 \%$, Sigma-Aldrich), Tryptone (Sigma-Aldrich), kanamycin sulfate (Sigma-Aldrich), D-(+)-glucose ( $\geq 99.5 \%$, SigmaAldrich), sodium chloride (Sigma-Aldrich), N-decanoylDL-homoserine lactone (C10-HSL, $\geq 97 \%$, SigmaAldrich), proteose peptone (Sigma-Aldrich), dimethyl sulfoxide (DMSO, Sigma-Aldrich), were used in anti-QS activities. The minimal inhibitory concentration (MIC) of the propolis extracts against the strains was determined using a 96-well microplate reader (Greiner Bio-One, sterile, PP, U-bottom). HPLC grade methanol, ethanol, formic acid, was purchased from Merck (Darmstadt, Germany). The phenolic compounds were used as standards in LC-MS/MS analysis which galangin, rutin trihydrate, kaempferol, quercetin hydrate, quercitrin, $p$ coumaric acid, trans-chalcone, caffeic acid phenethyl ester (CAPE), trans-ferulic acid, cinnamic acid, luteolin, pinocembrin, caffeic acid, and gallic acid were purchased from Sigma-Aldrich), $m$-coumaric acid was purchased from Fluka, protocatechuic acid, trans-isoferulic acid, daidzein, rosmarinic acid, syringic acid, $( \pm)$-catechin, $( \pm$ )naringenin, 3-4 dimethoxycinnamic acid, apigenin, benzoic acid, ellagic acid dihydrate, emodin, pinobanksin, vitexin, $( \pm)$ epicatechin, $( \pm)$ epigallocatechin, isorhamnetin, chrysin, methyl syringate, naringin, and myricetin were purchased from Santa-Cruz biotechnology. Ultrapure water was obtained from ELGA ${ }^{\circledR}$ LabWater, Purelab flex.

Propolis Collection and Extraction: Propolis samples were collected in Bursa by using a plastic propolis trap in May, July, and September 2015 (Civan Incorporation, Bursa, Turkey). Firstly, the propolis samples were removed from traps than were stored at -20 ${ }^{\circ} \mathrm{C}$ until extraction. A coffee bean grinder was used to create powder all propolis samples to homogenization after it was frozen at $-20^{\circ} \mathrm{C}$ (Delonghi $\mathrm{Kg} 49$, Hampshire, UK). Preparation of ethanol extract propolis (EEP); five grams of the homogenize propolis were weighed and added to $50 \mathrm{ml} \mathrm{70 \%} \mathrm{ethanol/water} \mathrm{(v/v)} \mathrm{in} \mathrm{an} \mathrm{Erlenmeyer}$ flask (100 ml) (33). Preparation of water extract propolis 
(WEP); five grams of the homogenize propolis were weighed and added to $50 \mathrm{ml}$ ultra-pure water (ELGA ${ }^{\circledR}$ LabWater, Purelab flex) in an Erlenmeyer flask (100 ml). Both extracts were shaken with using a shaker (Nüve SL35, Turkey) for an hour after followed by ultrasonication (Bandelin Sonorex RK100, Germany) for 30 minutes. The mixtures were filtered by using filter papers after waited one hour in the freezer at $+4{ }^{\circ} \mathrm{C}$ to remove the wax and bee part (Watman No: 1, UK). EEP and WEP were stored at $+4{ }^{\circ} \mathrm{C}$ until the experimental study. $5 \mathrm{ml}$ extract was poured into glass tubes, which was tared before and evaporated using a vacuum concentrator (Jouan, RC 1010) for HPLC-DAD analyses and determination of percent of resin (33). EEP and WEP resin determined as 313 $\mathrm{mg} / \mathrm{ml}, 112 \mathrm{mg} / \mathrm{ml}$ respectively. Both propolis extracts were adjusted to $100 \mathrm{mg}$ resin/ $\mathrm{ml}$ for anti-quorum sensing activity assays.

Validation of HPLC analyses method: Thirty-six phenolic compounds were injected as single and mixed to the HPLC-DAD to the determination of retention times, calibration curves, and other validation parameters (28). The phenolic compounds chromatogram was presented in Figure 1. Calibration curves were plotted by of 2, 4, 8, 16, and $32 \mu \mathrm{g} / \mathrm{mL}$ concentration of mixed phenolic compounds. All calibration curves of components showed good linearity (R2 between 0.997-0945). The limit of detection (LOD) and limit of quantification (LOQ) ranged from 0.09 to $1.6 \mu \mathrm{g} / \mathrm{ml}$ and 0.27 to $4.8 \mu \mathrm{g} / \mathrm{ml}$, respectively. The relative standard deviations values of precision test, coefficient of variation were less than $2.9 \%$ and $4.7 \%$.
Concentration of 8,16 , and $32 \mu \mathrm{g} / \mathrm{mL}$ mixed phenolic compound were spiked in propolis extracts to determine the recovery. The spiked propolis samples are analyzed five different days as five times for recovery, accuracy, and repeatability of the method. In the recovery test results of accuracy ranged from $80 \%$ to $108 \%$ and RSD values less than $3.2 \%$.

Analysis of HPLC-DAD: Ethanol and water extract dry propolis firstly was diluted as a $1 / 40$ ratio with its extraction solvent, and then filtered through a polyvinyl difluoride (PVDF) syringe filter (Millipore Millex-HV, $0.45 \mu \mathrm{m})$. Finally, $5 \mu \mathrm{L}$ was injected into the HPLC-DAD system $(n=3)(22)$. The EEP and WEP-analysis were performed using high-performance liquid chromatography (Shimadzu Kyoto, Japan). HPLC system was equipped with a pump (LC-20AD), auto-sampler (SIL 20 AC), detector (SPD-M20A), for separation was used by column intersil ODS ( 4.6 × $150 \mathrm{~mm}$ ID, $5 \mu \mathrm{m})$. The UV wavelength was set at $270-360 \mathrm{~nm}$. The column was eluted using a linear gradient as follows: mobile phase A $(0.1 \%$ formic acid in water) and mobile phase $\mathrm{B}$ (acetonitrile) with a flow rate of $1 \mathrm{~mL} / \mathrm{min}$. The gradient elution was applied; $3-10 \% \mathrm{~B}$ at $0,02-3 \mathrm{~min}, 10-13 \% \mathrm{~B}$ at $3-30 \mathrm{~min}$, $13-16 \% \mathrm{~B}$ at $30-60 \mathrm{~min}, 16-17 \% \mathrm{~B}$ at $60-70 \mathrm{~min}, 17-18 \%$ $\mathrm{B}$ at $70-80 \mathrm{~min}, 18-30 \% \mathrm{~B}$ at $80-120 \mathrm{~min}, 30-35 \% \mathrm{~B}$ at $120-135 \mathrm{~min}, 35-40 \% \mathrm{~B}$ at $135-170 \mathrm{~min}, 40-45 \% \mathrm{~B}$ at $170-$ $172 \mathrm{~min}, 45-60 \% \mathrm{~B}$ at $172-182 \mathrm{~min}, 60-90 \% \mathrm{~B}$ at $182-202$ $\mathrm{min}, 90 \% \mathrm{~B}$ at $202-203 \mathrm{~min}, 90-30 \% \mathrm{~B}$ at $203-205 \mathrm{~min}$ and $30-3 \% \mathrm{~B}$ at $205-206 \mathrm{~min}$. The column temperature was set at $+30{ }^{\circ} \mathrm{C}$.

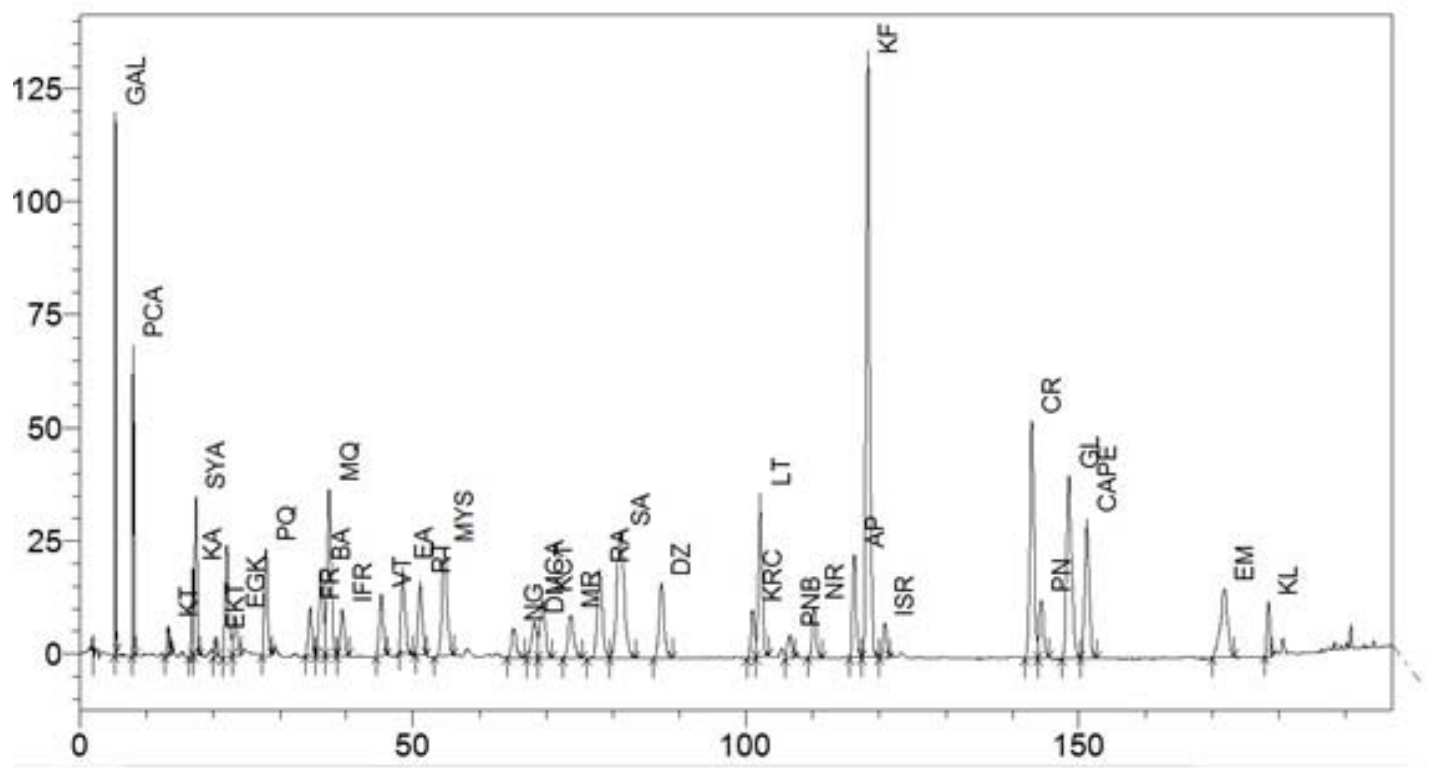

Figure 1. The HPLC-DAD chromatogram of mixed phenolic compounds in $270 \mathrm{~nm}$.

Gallic acid (GAL), protocatechuic acid (PCA), $( \pm$ )-catechin $(\mathrm{KT})$, caffeic acid (KA), syringic acid (SYA), $( \pm$ )epicatechin $(\mathrm{EKT})$, $( \pm$ )epigallocatechin (EGK), $p$-coumaric acid (PQ), trans-ferulic acid (FR), benzoic acid (BA), $m$-coumaric acid (MQ), trans-isoferulic acid (IFR), vitexin (VT), ellagic acid (EA), rutin (RT), methyl syringate (MYS), naringin (NG), 3-4 dimethoxycinnamic acid (DMCA), quercitrin (KCT), myricetin (MR), rosmarinic acid (RA), cinnamic acid (SA), daidzein (DZ), quercetin (KRC), luteolin (LT), pinobanksin (PNB), ( $( \pm$ )naringenin (NR), apigenin (AP), kaempferol (KF), isorhamnetin (ISR), chrysin (CR), pinocembrin (PN), galangin (GL), caffeic acid phenethyl ester (CAPE) emodin (EM)and trans-chalcone (KL). 


\section{Antimicrobial activity}

Microorganisms and conditions for cultivation: Staphylococcus aureus ATCC 25923, Listeria monocytogenes ATCC 7644, Escherichia coli ATCC 25922, and Candida albicans ATCC 10239 were obtained from the American Type Culture Collection. Streptococcus mutans CNCTC 8/77 was obtained from the Czechoslovak Collection of Type Cultures Institute of Hygiene and Epidemiology. The above-mentioned bacteria, except Streptococcus mutans, were cultured in Nutrient Broth (NB) at $37 \pm 0.1^{\circ} \mathrm{C}$; Streptococcus mutans were cultured in Brain Heart Infusion Broth (BHIB) at $37 \pm 0.1^{\circ} \mathrm{C}$, Candida albicans cultured in Sabouraud Dextrose Broth $(\mathrm{SDB})$ at $28 \pm 0.1^{\circ} \mathrm{C}$. Inoculate was prepared by adjusting the turbidity of the medium to match the 0.5 Mcfarland Standard. Dilutions of the suspension in $0.1 \%$ peptone $(\mathrm{w} / \mathrm{v})$ solution in sterile water were inoculated on NB, BHIB, SDB to check the viability of the preparation. The cultures of bacteria were maintained in their appropriate agar slants at $4^{\circ} \mathrm{C}$ throughout the study and used as stock cultures.

Agar Well Diffusion Methods: The antimicrobial activity of propolis extracts was studied by the well diffusion method $(18,34)$. The test microorganisms were activated in the above media at appropriate temperatures for $24 \mathrm{~h}$. Petri dishes containing $20 \mathrm{~mL}$ of Muller Hinton agar were prepared previously and inoculated with $0.1 \mathrm{ml}$ of $24 \mathrm{~h}$ broth culture of test microorganisms. After this stage, the plates were kept in the refrigerator for $30 \mathrm{~min}$. Then, the holes with a diameter of $6 \mathrm{~mm}$ have punched aseptically with a sterile cork borer, and a volume $(50 \mu \mathrm{L})$ of propolis extracts at desired concentration $(25,50,100$ $\mathrm{mg} / \mathrm{mL}$ ) were introduced into the wells. The petri dishes were incubated at $37^{\circ} \mathrm{C}$ for $24 \mathrm{~h}$. Then the diameter of the inhibition zone was measured with calipers in $\mathrm{mm}$. The antimicrobial activity was determined by measuring the clear zone around the wells.

\section{Anti-quorum sensing activity assay}

Bacterial strains, growth media, and conditions: The biomonitor strains Chromobacterium violaceum $\mathrm{CV}$ 026, Chromobacterium violaceum ATCC 12472, and Pseudomonas aeruginosa PA01 were used for the assay of QSI effects of the propolis extracts. CV 026 (growth with Kanamycin at $20 \mathrm{mg} / \mathrm{L}$ ) and $\mathrm{CV} 12472$ cultures were grown in Luria Bertani (LB) broth at $30{ }^{\circ} \mathrm{C}$ with shaking. PA01 cultures were grown on LB agar (LBA) plates at 37 ${ }^{\circ} \mathrm{C}$.

Determination of MIC: The MIC of propolis extracts was determined against biosensor strains (CV12472, CVO26, and PAO1) by broth microdilution method (35). MIC is defined as the minimum concentration of propolis extracts at which there was no visible growth of test strain. The test medium was
Mueller-Hinton Broth (MHB) and the density of bacteria was $5 \times 105$ colony-forming units $(\mathrm{CFU}) / \mathrm{mL}$. Cell suspensions $(200 \mu \mathrm{L})$ were inoculated into the wells of $96-$ well microtitre plates in the presence of propolis extracts with different final concentrations $(0.78,1.56,3.125,6.25$, $12.5,25,50,100 \mathrm{mg} / \mathrm{mL})$. The wells containing only MHB and MHB with inoculum were employed as negative and positive controls, respectively. The inoculated microplates were incubated at $37^{\circ} \mathrm{C}$ for $24 \mathrm{~h}$. The lowest concentration of the tested samples, which did not show any visual growth of tested organisms after macroscopic evaluation, was determined as MIC, which was expressed in $\mathrm{mg} / \mathrm{mL}$. Each assay was performed in triplicate for all microorganisms. Sub-MICs were selected for the assessment of anti-QS activity in the abovementioned strains.

Anti-Quorum Sensing (Anti-QS) Activity Assay: The Anti-QS activity of propolis extracts using CV 026 was assayed by the agar well diffusion method (14). In the presence of approximately a standardized amount of natural $\mathrm{C}_{6}$-AHL. Briefly, LB agar plates were spread with

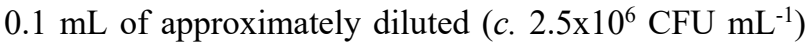
freshly grown cultures, and $6 \mathrm{~mm}$ diameter wells were cut and varying amounts $(50 \mu \mathrm{l})$ of appropriately diluted propolis extracts in ethanol were loaded along with natural $\mathrm{C}_{6}$-AHL. Plates were incubated for $18-24 \mathrm{~h}$ at $28{ }^{\circ} \mathrm{C}$ to check the inhibition of pigment production around the well. Growth inhibition, if any, was also recorded.

Violacein Inhibition Assay: The propolis extracts were subjected to the qualitative analysis to find out their QSI potentials against C. violaceum ATCC 12472 (20). Overnight culture $(10 \mu \mathrm{l})$ of $C$. violaceum (adjusted to 0.4 $\mathrm{OD}$ at $600 \mathrm{~nm}$ ) was added into wells of sterile microtiter plates (MTP) containing $200 \mu \mathrm{l}$ of LB broth and incubated in the presence and absence of sub-MIC concentrations of propolis extracts. These MTPs were incubated at $30^{\circ} \mathrm{C}$ for $16 \mathrm{~h}$ and observed for the reduction in violacein pigment production. The percentage of violacein inhibition was calculated by following the formula: percentage of violacein inhibition $=\left(\right.$ control $\mathrm{OD}_{585}$-test $\mathrm{OD}_{585} /$ controlOD 585$) \times 100$.

Anti-swarming Activity Assay: The anti-swarming potential of propolis extracts was performed by following the method specified by Packiavathy et al., 2012 (23). For this assay, $5 \mu \mathrm{l}(0.4 \mathrm{OD}$ at $600 \mathrm{~nm})$ overnight culture of PA01 were inoculated at the center of the swarming agar medium consisting of $1 \%$ peptone, $0.5 \% \mathrm{NaCl}, 0.5 \%$ agar and $0.5 \%$ of filter-sterilized D-glucose with increasing concentrations of propolis extracts $(25,50$ and $100 \mu \mathrm{g} / \mathrm{ml})$. The plates were then incubated at $30^{\circ} \mathrm{C}$ in an upright position for $16 \mathrm{~h}$. The reduction in swimming and swarming migration was recorded by measuring the swim and swarm zones of the bacterial cells after $16 \mathrm{~h}$. 
Statistical analysis: The results were presented as mean \pm SD of three independent experiments. Statistical differences were determined by one-way ANOVA followed by Dunnett's test and unpaired t-test using Graph pad Prism software. Differences were considered significant at $\mathrm{P} \leq 0.05$.

\section{Results}

Antimicrobial activities of propolis extracts against test microorganisms were conducted by well diffusion method, and antimicrobial results were given in Table 1 $(\mathrm{P}<0.05)$. Well diffusion test results reveal that both propolis extracts had an antimicrobial effect against Gram-positive strains and C. albicans. However, the propolis extracts had no antimicrobial effect against $E$. coli, which was a Gram-negative strain. While the highest antimicrobial effects were determined that inhibition zone of $20 \mathrm{~mm}$ against L. monocytogenes of WEP, $16 \mathrm{~mm}$ inhibition zones against $S$. aureus of EEP (Table 1). Both of the propolis extracts were found weak antimicrobial activity against $S$. mutans that inhibition zone between 6$9 \mathrm{~mm}$. WEP showed higher antibacterial activity than EEP. While both extracts showed inhibition effect against the Gram-positive bacteria and yeast, non-effect against the Gram-negative bacteria. It was revealed that the antimicrobial effect of both propolis extracts varied depend on the dose.
MIC results were obtained from the broth microdilution method of propolis extracts against biomonitor strains used for anti-QS tests were presented in Table 2. The lowest MIC concentration against $C$. violaceum CV026 was detected in EEP as $1.56 \mathrm{mg} / \mathrm{mL}$. However, the WEP against the same strain showed inhibition at a concentration of $50 \mathrm{mg} / \mathrm{ml}$. The MIC concentrations against $C$. violaceum CV12472 were detected in EEP $12.5 \mathrm{mg} / \mathrm{ml}$, and in WEP $25 \mathrm{mg} / \mathrm{ml}$, while the MIC against $P$. aeruginosa PA01 in both extracts was determined above $100 \mathrm{mg} / \mathrm{mL}$. Moreover, anti-quorum sensing and violacein pigment inhibition tests were conducted using MIC and sub-MICs propolis extracts.

The sub-MICs ranges were selected for anti-QS screening using CV026 strain and agar well diffusion method adopted in the presence of $\mathrm{C}_{6}$-AHL. The anti-QS activity test results of propolis extracts were given in Table 3 and Figure $2(\mathrm{P}<0.05)$. While the anti-QS activity of the EEP measured at the concentration of $1.56 \mathrm{mg} / \mathrm{ml}$ with an inhibition zone of $14.17 \pm 1.61 \mathrm{~mm}$ and the concentration $0.78 \mathrm{mg} / \mathrm{ml}$ with an inhibition zone of $11.5 \pm 0.5 \mathrm{~mm}$, the anti-QS activity of WEP was measured at $50 \mathrm{mg} / \mathrm{ml}$ concentration with an inhibition zone of $12.67 \pm 1.15 \mathrm{~mm}$. Anti-QS inhibition zones were observed decreased proportionally depending on the dose of both extracts.

Table 1. Antimicrobial activities of propolis extracts.

\begin{tabular}{|c|c|c|c|c|c|c|}
\hline \multirow{3}{*}{$\begin{array}{l}\text { Concentration } \\
\text { Microorganisms }\end{array}$} & \multicolumn{3}{|l|}{ WEP } & \multicolumn{3}{|l|}{ EEP } \\
\hline & $\begin{array}{l}\mathrm{mg} / \mathrm{mL} \\
100\end{array}$ & 50 & 25 & 100 & 50 & 25 \\
\hline & \multicolumn{6}{|c|}{ Inhibition zones $(\mathrm{mm} \pm \mathbf{S D})$} \\
\hline L. monocytogenes ATCC 7644 & $20 \pm 0.41^{\mathrm{a}}$ & $18 \pm 0.81^{\mathrm{b}}$ & $17 \pm 0.0^{\mathrm{c}}$ & $15 \pm 0.47^{\mathrm{a}}$ & $13 \pm 0.41^{\mathrm{b}}$ & $11 \pm 0.0^{\mathrm{c}}$ \\
\hline S. mutans CNCTC 8/77 & $9 \pm 0.47$ & $7 \pm 0.0$ & NI & $7 \pm 0.41$ & $6 \pm 0.0$ & NI \\
\hline S. aureus ATCC 25923 & $18 \pm 0.41^{\mathrm{a}}$ & $16 \pm 0.0$ & $15 \pm 0.0$ & $16 \pm 0.47^{\mathrm{a}}$ & $15 \pm 0.0$ & $13 \pm 0.47$ \\
\hline E. coli ATCC 25922 & NI & NI & NI & NI & NI & NI \\
\hline C. albicans ATCC 10239 & $15 \pm 0.47$ & $13 \pm 0.0^{\mathrm{b}}$ & $12 \pm 0.0^{\mathrm{c}}$ & $15 \pm 0.47$ & $11 \pm 0.0^{\mathrm{b}}$ & $10 \pm 0.0^{\mathrm{c}}$ \\
\hline
\end{tabular}

NI: No inhibition, WEP: Water extract propolis, EEP: Ethanol extract propolis, SD: Standard deviation a,b,c Values within a row with same superscripts differ significantly at $\mathrm{P}<0.05$ on the same concentration.

Table 2. MIC result of the propolis extracts against biosensor strains.

\begin{tabular}{|c|c|c|c|}
\hline & \multicolumn{3}{|c|}{ Microorganisms } \\
\hline & C. violaceum CV026 & $\begin{array}{r}\text { C. violaceum CV12472 } \\
\mathrm{mg} / \mathrm{mL}\end{array}$ & P. aeruginosa PA01 \\
\hline WEP & 50 & 25 & $>100$ \\
\hline EEP & 1.56 & 12.5 & $>100$ \\
\hline
\end{tabular}

WEP: water extract propolis, EEP: ethanol extract propolis. 
Table 3. Anti-QS activity of propolis extracts against Chromobacterium violaceum CV026.

\begin{tabular}{llc}
\hline & Antimicrobial Activity & Anti-QS activity \\
\hline WEP (mg/mL) & & Inhibition zones (mm) \pm SD \\
50 & NI & $12.67 \pm 1.15$ \\
40 & NI & $11.5 \pm 0.5$ \\
30 & NI & $11.0 \pm 0.5$ \\
20 & NI & $10.67 \pm 0.58$ \\
EEP (mg/mL) & & \\
1.56 & $10.5 \pm 0.5$ & $14.17 \pm 1.61$ \\
0.78 & $9.33 \pm 0.76$ & $11.5 \pm 0.5$ \\
0.39 & $8.5 \pm 0,5$ & $10.17 \pm 0.29$ \\
0,195 & $8.0 \pm 0$ & $9.67 \pm 0.29$ \\
C10HSL & NI & $32.17 \pm 1.61$ \\
Ethanol & $8.17 \pm 0.29$ & $8.5 \pm 0.5$ \\
\hline
\end{tabular}

WEP: water extract propolis, EEP: ethanol extract propolis, SD: standard deviation, NI: No inhibition.

a

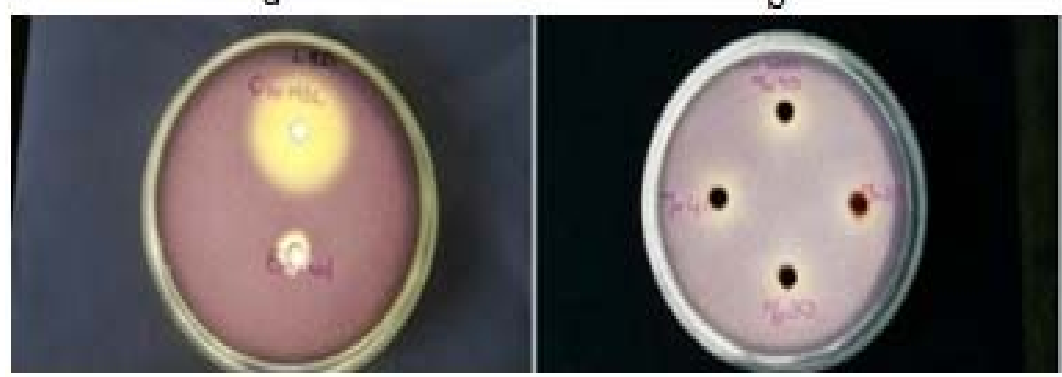

Figure 2. Anti-QS activity by propolis extracts against biosensor strain CV026 using agar well diffusion method. a: $\mathrm{C}_{10} \mathrm{HSL}$ control, b: water extract propolis plate, $\mathrm{c}$ : ethanol extract propolis.
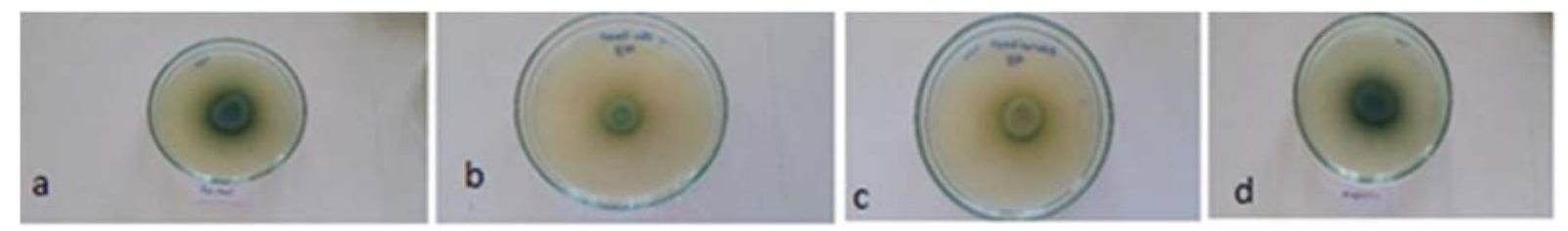

Figure 3. Swarming motility inhibition of propolis extracts in PA01.

a: control group, b. water extract propolis $(25 \mu \mathrm{g} / \mathrm{mL})$. c. ethanol extract $(25 \mu \mathrm{g} / \mathrm{mL}) \mathrm{d}$. Ampicillin $(10 \mu \mathrm{g} / \mathrm{mL})$.

The violacein pigment inhibition tests of propolis extracts against CV 12472 strain were determined by the microplate dilution method using MIC and sub-MIC (Table 4, $\mathrm{P}<0.05$ ). Although both extracts inhibited the production of violacein pigment $100 \%$ in MIC, EEP was observed to more inhibit the production of violacein pigment compare to WEP, according to Sub-MIC (Table 4).

Inhibition of swarming motilities of WEP and EEP were determined using strain. Results were presented in Table 5 and Figure $3(\mathrm{P}<0.05)$. The propolis extracts performed swarming motility inhibition between $39.13 \%$ and $13.04 \%$, depending on concentration according to results. EEP showed higher rates of swarming inhibition activity than WEP (Table5).

HPLC analysis revealed that the number of phenolic compounds in the EEP was more than the WEP apart from benzoic acid and cinnamic acid. Some phenolic compounds were not determined in both of propolis extracts which gallic acid, m-coumaric acid, methyl syringate, naringin, quercetin, myricetin, rosmarinic acid, and daidzein (Table 6). While syringic acid,
$( \pm$ )epigallocatechin, vitexin, rutin, and trans-chalcone were only determined in WEP, catechin, caffeic acid, ellagic acid, pinobanksin, naringenin, and emodin were determined only in EEP. The present study generally indicated that the phenolic compounds in propolis more soluble in EEP.

WEP inhibition zones were determined to be larger than EEP when the inhibition zones of the antimicrobial activity was examined (Table 1). The reason for the more antibacterial activity of WEP to EEP was thought to be due to phenolic compounds which are more soluble in water or only in WEP. Although the antibacterial activity of EEP was weaker compared to WEP, anti-quorum sensing, violacein pigment inhibition, and swarming motility inhibition activity was determined higher than WEP. The phenolic compounds which are more soluble in ethanol or only consist of EEP may have caused the high anti-quorum sensing, violacein pigment inhibition, and swarming motility inhibition activity than the WEP (Table 2, 3, 4, and 5). 
Table 4. Concentration-dependent inhibition of violaceum by propolis extracts in C. violaceum CV12472.

\begin{tabular}{lcc}
\hline Propolis concentration & Reduction in the absorbance of violacein (\%) & \\
\cline { 2 - 3 }$(\mathbf{m g} / \mathbf{m L})$ & $\mathbf{W E P} \pm \mathbf{S D}$ & $\mathbf{E E P} \pm \mathbf{S D}$ \\
$\mathrm{MIC}$ & $100 \pm 0.01$ & $100 \pm 0.01$ \\
$\mathrm{MIC} / 2$ & $72.24 \pm 0.01$ & $85.94 \pm 0.03$ \\
$\mathrm{MIC} / 4$ & $46.77 \pm 0.02$ & $81.65 \pm 0.03$ \\
$\mathrm{MIC} / 8$ & $41.95 \pm 0.08$ & $69.17 \pm 0.01$ \\
$\mathrm{MIC} / 16$ & $36.47 \pm 0.08$ & $67.46 \pm 0.01$ \\
MIC/32 & $20.57 \pm 0.07$ & $39.01 \pm 0.003$ \\
MIC/64 & $5.54 \pm 0.06$ & $26.93 \pm 0.01$ \\
\hline
\end{tabular}

WEP: water extract propolis, EEP: ethanol extract propolis, SD: standard deviation.

Table 5. Swarming motility inhibition in Pseudomonas aeruginosa PA01.

\begin{tabular}{llc}
\hline & \multicolumn{2}{l}{ Swarming motility inhibition (\%) } \\
\cline { 2 - 3 } Extract concentration $(\boldsymbol{\mu g} / \mathbf{m L})$ & $\mathbf{W E P} \pm$ SD & EEP \pm SD \\
100 & $30.43 \pm 0.62^{\mathrm{a}}$ & $39.13 \pm 0.35^{\mathrm{a}}$ \\
50 & $26.09 \pm 0.82^{\mathrm{b}}$ & $34.78 \pm 0.43^{\mathrm{b}}$ \\
25 & $13.04 \pm 0.33^{\mathrm{c}}$ & $30.43 \pm 0.22^{\mathrm{c}}$ \\
Ampicillin $(10 \mu \mathrm{g} / \mathrm{mL})$ & & $26.09 \pm 0.41$ \\
Kanamycin $(10 \mu \mathrm{g} / \mathrm{mL})$ & \multicolumn{2}{c}{ No } \\
Ethanol & \multicolumn{2}{c}{ No } \\
\hline
\end{tabular}

WEP: water extract propolis, EEP: ethanol extract propolis, SD: standard deviation

a,b,c Values within a row with same superscripts differ significantly at $\mathrm{P}<0.05$ on the same concentration.

Table 6. Phenolic Compounds in Propolis Samples Analysis (HPLC-DAD).

\begin{tabular}{|c|c|c|c|}
\hline Phenolic Compounds & R time (min) & WEP (mg/kg) & EEP (mg/kg) \\
\hline Gallic acid & 5.338 & ND & ND \\
\hline Protocatechuic acid & 7.996 & 14.61 & 15.50 \\
\hline$( \pm)$-Catechin & 13.232 & ND & 12.91 \\
\hline Caffeic acid & 16.832 & ND & 1021.71 \\
\hline Syringic acid & 17.376 & 2.22 & ND \\
\hline$( \pm)$ epicatechin & 20.196 & 6.82 & 31.02 \\
\hline$( \pm)$ Epigallocatechin & 23.248 & 3.91 & ND \\
\hline p-Coumaric acid & 27.822 & 17.76 & 265.77 \\
\hline trans-Ferulic acid & 34.456 & 24.60 & 141.52 \\
\hline Benzoic acid & 36.224 & 197.21 & 130.90 \\
\hline m-Coumaric acid & 37.280 & ND & ND \\
\hline trans-Isoferulic acid & 39.265 & 302.02 & 425.38 \\
\hline Vitexin & 45.043 & 5.63 & ND \\
\hline Ellagic acid & 48.294 & ND & 30.93 \\
\hline Rutin & 50.900 & 3.74 & ND \\
\hline Methyl syringate & 54.603 & ND & ND \\
\hline Naringin & 64.914 & ND & ND \\
\hline 3-4 Dimethoxycinnamic acid & 68.032 & 527.82 & 1946.41 \\
\hline Quercitrin & 69.248 & ND & ND \\
\hline Myricetin & 73.486 & ND & ND \\
\hline Rosmarinic acid & 78.344 & ND & ND \\
\hline Cinnamic acid & 80.945 & 189.22 & 142.10 \\
\hline Daidzein acid & 87.101 & ND & ND \\
\hline Quercetin & 100.798 & 22.26 & 78.31 \\
\hline Luteolin & 102.368 & 2.74 & 16.36 \\
\hline Pinobanksin & 106.423 & ND & 2228.45 \\
\hline$( \pm)$ Naringenin & 110.070 & ND & 50.07 \\
\hline Apigenin & 116.113 & 82.41 & 251.58 \\
\hline Kaempferol & 118.147 & ND & 100.72 \\
\hline Isorhamnetin & 120.681 & 27.07 & 173.34 \\
\hline Chrysin & 142.719 & 618.54 & 1472.02 \\
\hline Pinocembrin & 144.153 & 357.77 & 1859.83 \\
\hline Galangin & 148.185 & 1095.85 & 3655.08 \\
\hline CAPE & 150.990 & 69.14 & 3319.89 \\
\hline Emodin & 171.582 & ND & 44.67 \\
\hline trans-Chalcone & 178.308 & 77.33 & ND \\
\hline
\end{tabular}

ND: non-determined, R time: retention time, WEP: water extract propolis, EEP: ethanol extract propolis. 


\section{Discussion and Conclusion}

Researchers have studied the effectiveness of propolis on Gram-negative and Gram-positive bacteria (2, $24,27,31)$. Results of the present study are similar to previous studies which showed tht propolis has an antibacterial activity gram-positive bacteria and yeast, while it doesn't have any effect on gram-negative bacteria $(4,12,19,24)$. However, previous studies investigating the anti-QS activity of propolis with different methods were quite limited. Lamberte et al. (16) determined the ethanol extract propolis has anti-QS activity against Chromobacterium violaceum ATCC 12472 and Pseudomonas aeruginosa PAO1. While Lamberte et al. (16) reveal that low doses prevented biofilm formation than the high doses, the present study was increasing the dose-dependent. Savka et al. (29) found the violacein inhibition on Chromobacterium violaceum CV026 of propolis, which has higher in pinocembrin and flavonoid. Similarly, in the present study was found violacein inhibition higher in EEP that contains more pinocembrin and flavonoids than WEP. Gemiarto et al. (11) determined the higher antibacterial activity and anti QS activity than was detected in the present study, while similar results were obtained for violacein inhibition. Bulman et al. (6) revealed that violacein inhibition on Chromobacterium violaceum (CV026), and anti-swarming activity on Pseudomonas aeruginosa (PAO1) of the propolis. Kasote et al. (13) found an antifungal activity of propolis which has high content pinocembrin and also violacein inhibition activity of propolis, which has high content caffeic acid. Although a significant difference was observed in the present study between EEP $(1859.83 \mathrm{mg} / \mathrm{kg})$ and WEP $(357.77 \mathrm{mg} / \mathrm{kg}$ ) in terms of pinocembrin level, no significant difference was found in antifungal activity. Similarly, in the present study, EEP that has high levels of caffeic acid was found to be higher in the inhibition of violacein. De Marco et al. (8) did not report the antiswarming activity of $P$. aeruginosa of $85 \%$ ethanol extract propolis. While the amount of pinocembrin, galangin, and chrysin in the propolis was found to be higher than the present study, the CAPE was lower. Moreover, Djais et al. (9) have found no effect of propolison biofilm formation on S. mutans (ATCC 25175).

In the present study, it was determined that propolis has an antimicrobial activity due to dose and extraction solvent against Gram-positive bacteria and yeasts. Numerous studies have demonstrated that propolis possesses a marked antibacterial and moderate antifungal activites. However, both propolis extracts did not show any activity against Gram-negative bacteria. It is generally recognized that Gram-positive bacteria are more susceptible to the antibacterial activity of propolis than Gram-negative bacteria. Anti-quorum sensing, violacein inhibition, and anti-swarming activity of propolis were also determined depending on the dose and extraction solvent. Although EEP had lower antibacterial activity when compared with WEP, anti-quorum sensing, violacein inhibition, and anti-swarming activity were found out higher than WEP. The results of this study show that the phenolic compounds in propolis have a direct effect on antibacterial activity, anti-quorum sensing, violasein inhibition and anti-swarming activity depending on the extraction solvent.

\section{Financial Support}

This research received no grant from any funding agency/sector.

\section{Ethical Statement}

This study does not present any ethical concerns.

\section{Conflict of Interest}

The authors declared that there is no conflict of interest.

\section{References}

1. Alvarez MV, Moreira MR, Ponce A (2012): Antiquorum Sensing and Antimicrobial Activity of Natural Agents with Potential Use in Food. J Food Saf, 32, 379-387.

2. Astani A, Zimmermann S, Hassan E, et al (2013): Antimicrobial activity of propolis special extract GH 2002 against multidrug-resistant clinical isolates. Die Pharmazie, 68, 695-701.

3. Banskota AH, Tezuka Y, Kadota S (2001): Recent progress in pharmacological research of propolis. Phytother Res, 15, 561-571.

4. Boonsai P, Phuwapraisirisan P, Chanchao C (2014): Antibacterial activity of a cardanol from Thai Apis mellifera propolis. Int J Med. Sci, 11, 327.

5. Bulman Z, Hudson A, Savka MA (2011). Propolis, a product of the bee hive, has an antagonistic affect on quorum-sensing regulated bioluminescence, gene transcription and motility. The FASEB Journal, 25, 948.

6. Bulman Z, Le P, Hudson AO, et al (2011): A novel property of propolis (bee glue): anti-pathogenic activity by inhibition of $\mathrm{N}$-acyl-homoserine lactone mediated signaling in bacteria. J Ethnopharmacol, 138, 788-797.

7. De Castro S (2001): Propolis: biological and pharmacological activities. Therapeutic uses of this beeproduct. Annu Rev Biomed, 3, 49-83.

8. De Marco S, Piccioni M, Pagiotti R, et al (2017): Antibiofilm and antioxidant activity of propolis and bud poplar resins versus Pseudomonas aeruginosa. eCAM, 2017.

9. Djais AA, Putri N, Jemmy J, et al (2019): Effect of Propolis on Streptococcus mutans Biofilm Formation. Pesqui Bras Odontopediatria Clin Integr, 19, 5221.

10. Dong Y-H, Zhang L-H (2005): Quorum sensing and quorum-quenching enzymes. J Microbiol , 43, 101-109.

11. Gemiarto AT, Ninyio NN, Lee SW, et al (2015): Isoprenyl caffeate, a major compound in manuka propolis, is a 
quorum-sensing inhibitor in Chromobacterium violaceum. Anton Leeuw Int J G, 108, 491-504.

12. Gonsales G, Orsi R, Fernandes Júnior A, et al (2006): Antibacterial activity of propolis collected in different regions of Brazil. J Venom Anim Toxins Incl Trop Dis, 12, 276-284.

13. Kasote D, Ahmad A, Chen W, et al (2015): HPTLC-MS as an efficient hyphenated technique for the rapid identification of antimicrobial compounds from propolis. Phytochemistry Letters, 11, 326-331.

14. Koh KH, Tham F-Y (2011): Screening of traditional Chinese medicinal plants for quorum-sensing inhibitors activity. J Microbiol Immunol Infect, 44, 144-148.

15. Kubiliene L, Laugaliene V, Pavilonis A, et al (2015): Alternative preparation of propolis extracts: comparison of their composition and biological activities. BMC Complement Altern Med, 15, 156.

16. Lamberte LE, Cabrera EC, Rivera WL (2011): Activity of the Ethanolic Extract of Propolis (EEP) as a Potential Inhibitor of Quorum Sensing-Mediated Pigment Production in Chromobacterium violaceum and Virulence Factor Production in Pseudomonas aeruginosa. Philipp Agric Sci, 94, 14-22.

17. Lotfy M (2006): Biological activity of bee propolis in health and disease. Asian Pac J Cancer Prev, 7, 22-31.

18. Magaldi S, Mata-Essayag S, De Capriles $\mathrm{CH}$, et al (2004): Well diffusion for antifungal susceptibility testing. Int J Infect Dis, 8, 39-45.

19. Majiene D, Trumbeckaite S, Pavilonis A, et al (2007): Antifungal and antibacterial activity of propolis. Curr Nutr Food Sci, 3, 304-308

20. McLean RJ, Pierson III LS, Fuqua C (2004): A simple screening protocol for the identification of quorum signal antagonists. J Microbiol Methods, 58, 351-360.

21. Noori A, Al-Ghamdi A, Ansari MJ, et al (2012): Synergistic effects of honey and propolis toward drug multiresistant Staphylococcus aureus, Escherichia coli and Candida albicans isolates in single and polymicrobial cultures. Int J Med Sci, 9, 793.

22. Nyandwi R, Kılı̧ AS, Çelik M, et al (2019): Determination and Quantification of Gallic Acid in Raw Propolis by High-performance Liquid ChromatographyDiode Array Detector in Burundi. East Afr J Sci, 1, 43-48.

23. Packiavathy IASV, Agilandeswari P, Musthafa KS, et al (2012): Antibiofilm and quorum sensing inhibitory potential of Cuminum cyminum and its secondary metabolite methyl eugenol against Gram negative bacterial pathogens. Food Res Int, 45, 85-92.

24. Pobiega K, Kraśniewska K, Derewiaka D, et al (2019): Comparison of the antimicrobial activity of propolis extracts obtained by means of various extraction methods. $\mathrm{J}$ Food Sci Technol, 56, 5386-5395.

25. Przybylek I, Karpiński TM (2019): Antibacterial properties of propolis. Molecules, 24, 2047.

26. Rasmussen TB, Givskov M (2006): Quorum-sensing inhibitors as anti-pathogenic drugs. Int J Med Microbiol, 296, 149-161.

27. Santos HCD, Vieira DS, Yamamoto SM, et al (2019): Antimicrobial activity of propolis extract fractions against Staphylococcus spp. isolated from goat mastitis. Pesqui Vet Bras, 39, 954-960.

28. Sariyev R, Çayci M, Oruç HH (2019): Azerbaycan Propolislerinin Fenolik Madde İçerikleri ve Kalite Açısından Değerlendirilmesi. J Res Vet Med, 38, 1-6.

29. Savka MA, Dailey L, Popova M, et al (2015): Chemical composition and disruption of quorum sensing signaling in geographically diverse United States propolis. eCAM, 2015.

30. Sforcin JM, Bankova V (2011): Propolis: is there a potential for the development of new drugs? Journal of Ethnopharmacology, 133, 253-260.

31. Silva JC, Rodrigues S, Feás X, et al (2012): Antimicrobial activity, phenolic profile and role in the inflammation of propolis. Food ChemToxicol, 50, 1790-1795.

32. Song X, Xia Y-X, He Z-D, et al (2018): A review of natural products with anti-biofilm activity. Curr Org Chem, 22, 789817.

33. Sorucu A, Oruç HH (2019): Determination of biologically active phenolic compounds in propolis by $L C-M S / M S$ according to seasons and altitudes. J Food Meas Charac, 13, 2461-2469.

34. Volpi N, Bergonzini G (2006): Analysis of flavonoids from propolis by on-line HPLC-electrospray mass spectrometry. J Pharm Biomed Anal, 42, 354-361

35. Wayne P (2011): Clinical and laboratory standards institute. Performance standards for antimicrobial susceptibility testing. 